\title{
Parasites in rodent coprolites from the historical archaeological site Alero Mazquiarán, Chubut Province, Argentina
}

\author{
Norma Haydée Sardella/ ${ }^{+}$, Martín Horacio Fugassa \\ Consejo Nacional de Investigaciones Científicas y Técnicas, Departamento de Biología, Facultad de Ciencias Exactas y Naturales, \\ Funes 3250, 7600 Mar del Plata, Argentina
}

\begin{abstract}
The aim of this study was to examine the parasitic remains that were found in rodent coprolites collected from the

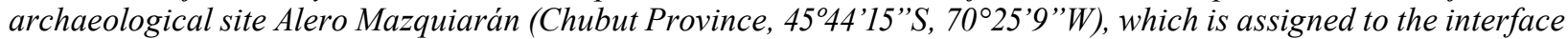
of the Araucanian and Tehuelche cultures, dated at $212 \pm 35$ years B.P. The faecal material from two unidentified rodent species (X-10 and X-11) was collected from one human pelvic cavity found in a multiple burial. The faecal samples were processed and examined using paleoparasitological procedures. The X-10 coprolites were positive for eggs of Monoecocestus $s p$. (Cestoda: Anoplocephalidae) and the X-11 faeces were positive for Pterygodermatites $s p$. (Nematoda: Rictulariidae), Trichosomoides sp. (Nematoda: Trichosomoididae) and Monoecocestus sp. In this study, we discuss parasitic life cycles, the zoonotic importance of parasites and the behaviour of the aboriginal people.
\end{abstract}

Key words: paleoparasitology - helminths - rodents - Patagonia - nematodes - anoplocephaliids

Parasites are useful as biological markers for the interpretation of the ecology of their hosts; they also play important roles in regulating the populations and communities of the hosts that they infect (Williams et al. 1992, Poulin 2007). In addition, parasites can be used as tags to determine the history of their hosts (Manter 1967, Brooks 1979, Morand et al. 2006). Helminth eggs, found in faeces and in sediments or other materials, vary widely in their ability to resist desiccation and destruction. Eggs are one of the most resilient stages in the life cycle of parasitic worms. Therefore, inferences can be made regarding evolutionary time using the recognition of eggs collected from old infected materials, i.e., from coprolites (Pike 1968).

In the archaeological site named Alero Mazquiarán (Chubut Province, Argentina), a multiple human burial was discovered. Parasites attributed to rodents, including several eggs of Trichuris sp. (Nematoda), one egg probably of taeniid, and two eggs of Anoplocephalidae (Cestoda) were recovered from sediment in one human pelvic cavity. Along with the sediment, rodent coprolites of two distinct morphological aspects (X-10 and X-11) were discovered. These samples were processed and examined microscopically. The presence of oribatid mites, Moniezia sp., Capillaria sp., Trichuris sp., ascaridid eggs, and differences in the parasite burden of both rodent faeces were available from previously published parasitological data (Fugassa 2006a, b).

The aim of this paper was to broaden the current paleoparasitological information using a new set of obser-

Financial support: FONCyT (PICTO 04-849, PICT 06-1520), Universidad Nacional de Mar del Plata, CONICET

+ Corresponding author: sardella@mdp.edu.ar

Received 29 September 2008

Accepted 21 January 2009 vations of the preserved coprolites, $\mathrm{X}-10$ and $\mathrm{X}-11$. The purpose of this study was to review the parasite fauna and to examine the existence of potentially zoonotic parasites and the role of rodents in ancient human populations in Patagonia.

\section{MATERIALS AND METHODS}

Alero Mazquiarán is an archaeological site located in the South of Chubut Province, Argentina (45\%44'15"S, $70^{\circ} 25^{\prime} 9^{\prime \prime} \mathrm{W}$ ) (Fig. 1), assigned to the interface of the Araucanian and Tehuelche cultures. This site is a rock shelter oriented eastwards antecedent to Rio Guenguel, and protected from the prevailing winds in the region. A multiple burial composed of five individuals was discovered at this site. Samples from the traces of clothes were dated to $212 \pm 35$ years B.P., corresponding to historical times (Pérez de Micou 2006).

Coprolites were inventoried and processed individually as described in Fugassa (2006a). The examination consisted of the external observation of faeces (colour, texture, inclusions and measures) according to Chame (2003) and Jouy-Avantin (2003). Two types of faeces with similar dimensions were identified and processed, X-10 and $\mathrm{X}-11$ (Fig. 2). Three $1,5 \mathrm{~mL}$ microcentrifuge tubes with a mixture of X-10 coprolites (7,1 mm length $\mathrm{x} 3 \mathrm{~mm}$ width) (soft, crumbled, fibrous, light textured, gray-green ochre coloured) and three tubes with a mixture of X-11 coprolites ( $7 \mathrm{~mm}$ length $\mathrm{x} 2,4 \mathrm{~mm}$ width) (hard and heavier textured, compact, gray-brown coloured, dark content) were sampled (Fugassa 2006a, b). Faeces were fully processed by rehydration in an aqueous solution of tris-sodium phosphate $0.5 \%$ in a glass tube for one week, followed by incubation at $4{ }^{\circ} \mathrm{C}$ to prevent overgrowth of fungi and spontaneous sedimentation (Lutz 1919). The material that was sedimented into the tube was recovered with a pipette and 10 slides of each sample were observed, with the addition of one drop of glycerine. Eggs of the parasites were measured and photographed at $40 \mathrm{X}$ magnification. 


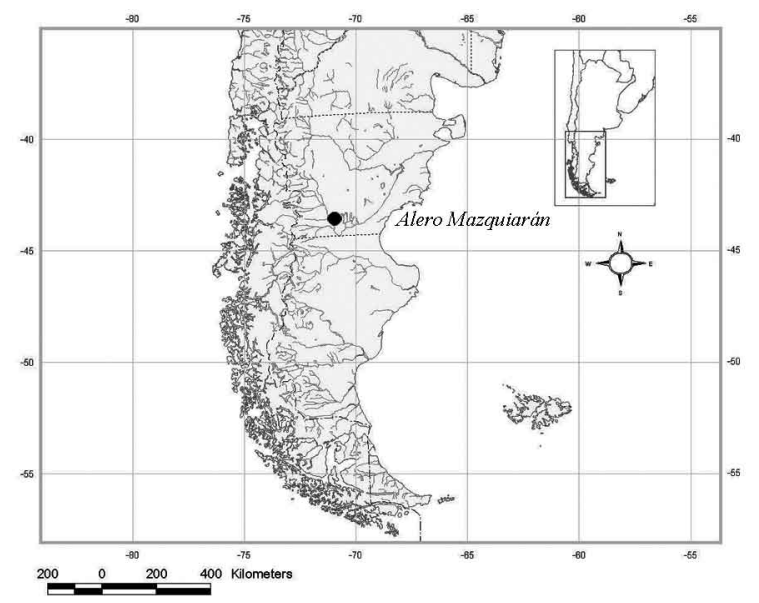

Fig. 1: geographic location of Alero Mazquiarán, Chubut Province, Argentina.

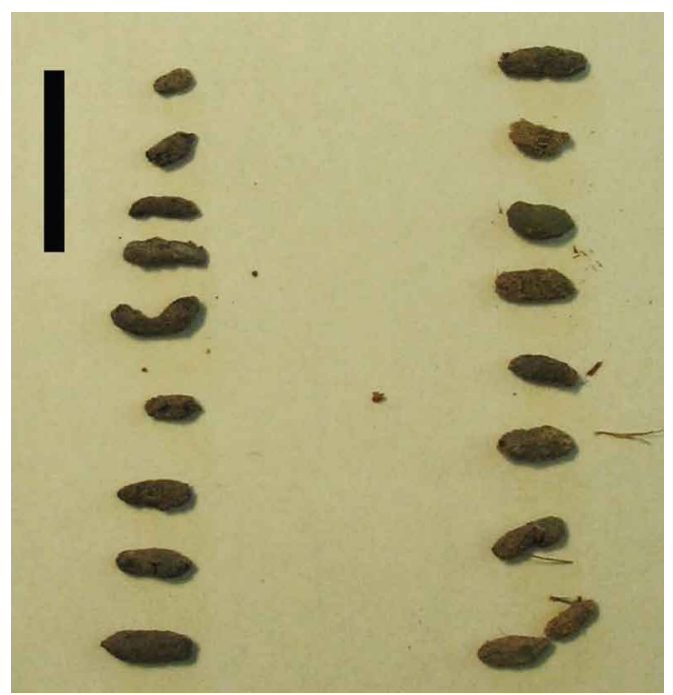

Fig. 2: macroscopic aspect of X-10 and X-11 coprolites examined. Bar $=20 \mathrm{~mm}$.

\section{RESULTS}

Paleoparasitological results indicated that X-10 and $\mathrm{X}-11$ coprolites belonged to two different individuals and likely to two distinct species. The parasite contents of both faeces were as follows.

Sample X-10 - A total of 47 Cestoda eggs belonging to the order Cyclophyllidea, family Anoplocephalidae, with characteristics attributable to genus Monoecocestus Beddard, 1914, were found (Fig. 3A). The measurements of the eggs were 50-62.5 $\mu \mathrm{m}$ in length $(58.87 \pm 3.07$; $\mathrm{n}=30)$ and 50-62.5 $\mu \mathrm{m}$ in width $(58.42 \pm 3.02 ; \mathrm{n}=30)$.

Sample X-11 - Thick walled smoothed eggs $(\mathrm{n}=8)$ embryonated with coiled larvae, $51.72 \mu \mathrm{m} \pm 2.4$ long (48.75-51.25) by $37.97 \mu \mathrm{m} \pm 1.88$ wide (35-37.5) were found (Fig. 3B). Through examination of the egg wall characteristics, the eggs were identified as being from nematodes of the genus Pterygodermatites Wedl, 1861 (class Adenophorea, order Spirurida, family Rictulariidae). Microscopic remains of unidentified insect cuticles were also discovered in the coprolites. Eggs from an additional nematode $(\mathrm{n}=13)$ with smooth walls and somewhat prominent polar plugs were also recovered. Most of these eggs contained larvae. These eggs measured $68.52 \mu \mathrm{m} \pm 3.66$ in length $(65-75)$ and $49.66 \mu \mathrm{m} \pm 2.31$ in width (45-52.5). During the rehydration process, a larva was extruded from one of the eggs (Fig. 3C, D). This parasite was identified as belonging to order Enoplida, superfamily Trichinelloidea, family Trichosomoididae Hall, 1916, Trichosomoides Raillet, 1895, likely Trichosomoides crassicauda (Bellingham, 1840) Raillet, 1895. Only five eggs of Cestoda Anoplocephalidae were found in sample X-11 and one of these eggs could be measured. This egg measured at $62.5 \mu \mathrm{m}$ long and $62.5 \mu \mathrm{m}$ wide and was identified as Monoecocestus sp., similar to those of sample X-10.

\section{DISCUSSION}

It was not currently possible to identify the specific biological origin of the rodent coprolites. Nevertheless, there is information available with respect to both the current and fossil rodent communities living in relative proximity of the area covered in this study $\left(45^{\circ} \mathrm{S}, 70^{\circ} \mathrm{W}\right)$. These known rodents have the ability to produce faeces with aspects and sizes similar to those that we discovered at the Alero Mazquiarán site. Monjeau et al. (1997), Pardiñas et al. (2003) and Teta et al. (2005) recognized the ubiquitous presence of sigmodontine rodents of small to medium size of Abrothrix olivaceus, Abrothrix longipilis, Eligmodontia morgani, Reithrodon auritus and others, in Chubut province. Pardiñas et al. (2003) communicated that Rattus sp. was absent in samples from Miocene to Holocene, in Patagonia. Two of the species mentioned below in addition to another two unidentified species could be hosts of Trichosomoides.

Spirurina include a diverse group of nematodes that use intermediate hosts such as arthropods, insects and crustaceans. Rictulariodea are a homogeneous group comprising approximately 50 species. They are found freely in the lumen, or firmly attached to the intestinal mucosa of their hosts. Representative eggs of the genus Pterygodermatites are oval, smooth, thick walled and contain a single larva in their interior. In the digestive tract of the intermediate hosts, including orthopterans, cockroaches, locusts, beetles e. g., depending on temperature, develop potentially infective larvae 3 . There are parathenesis in carnivores, with evidence of disease in humans (Anderson 2000). Definitive hosts are carnivores (canids, felids, mustelids), rodents (Anderson 2000), dasipodids and didelphids (Navone \& Lombardero 1980) and bats (Quentin 1969).

The genus Pterygodermatites Wedl, 1861 includes five sub-genera: Pterygodermatites, Paucipectines, $\mathrm{Ne}$ opaucipectines, Mesopectines and Multipectines. These sub-types are differentiated by their anatomy and parasitic specificity (Navone \& Lombardero 1980). In Argentina, $P$. (Multipectines) cahirensis was found in several felids 


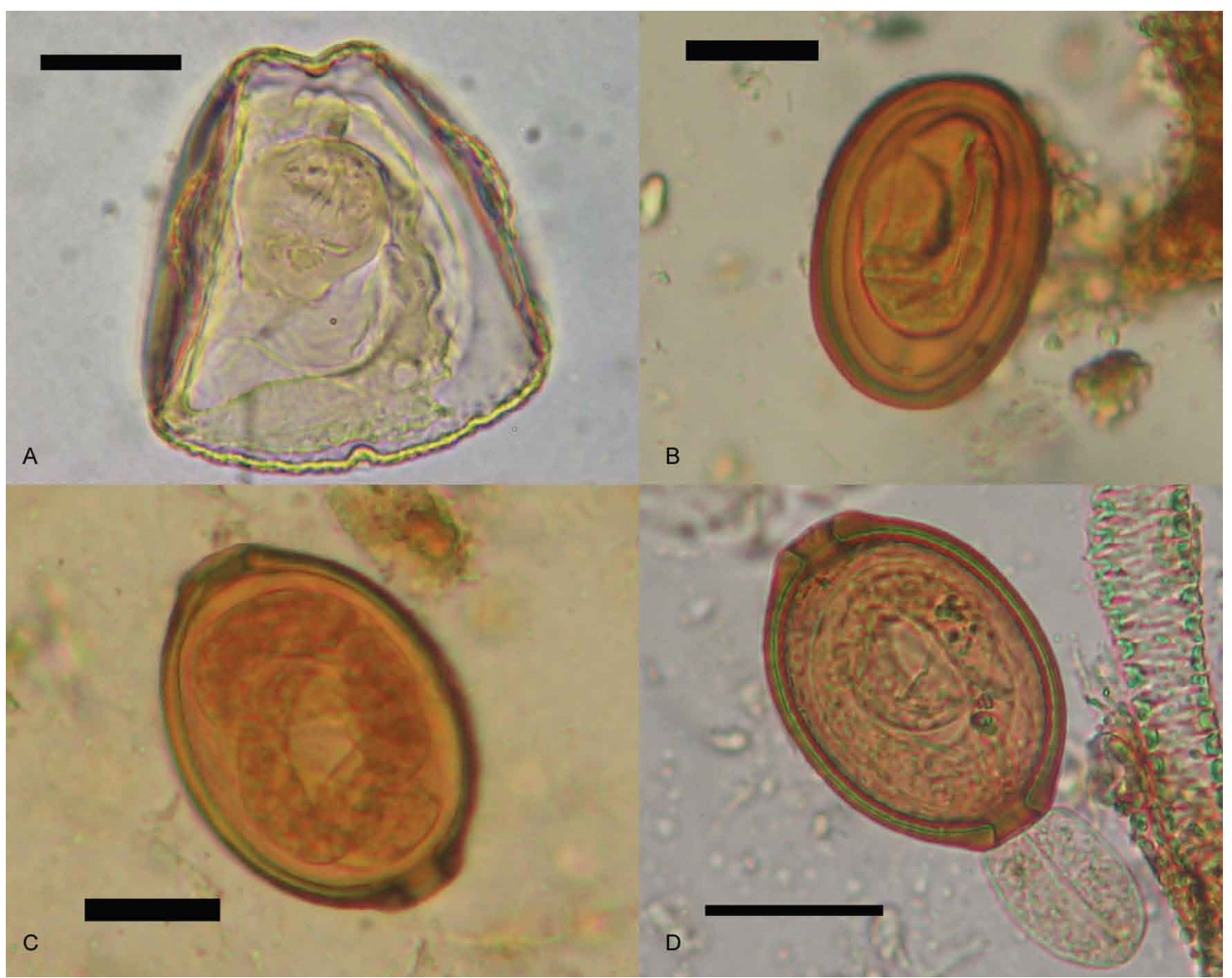

Fig. 3: A: egg of Monoecocestus sp. at 100X (onchospheral hooks can be observed); B: embryonated egg of Pterygodermatites sp.; C: embryonated egg of Trichosomoides, probably T. crassicauda: D: embryonated egg of Trichosomoides, probably T. crassicauda, with the larvae partially outside. Bar $=20 \mu \mathrm{m}$.

(Beldoménico et al. 2005). The subgenus Paucipectines is represented by the following species that infect xenarthrans, marsupials and cricetid rodents: Pterygodermatites (P.) massoiai (Sutton 1979) in Graomys griseoflavus griseoflavus from Mendoza (Sutton 1979); Pterygodermatites (P.) chaetophracti (Navone \& Lombardero 1980) in Chaetophractus villosus and Dasypus hybridus from Santa Fé, Cordoba and Buenos Aires (Navone \& Lombardero 1980) and in Tolypeutes matacus from Santiago del Estero (Navone 1987); Pterygodermatites (P.) azarai (Sutton 1984) in Akodon azarae from Buenos Aires (Sutton 1984); Pterygodermatites (P.) kozeki (Chabaud \& Bain 1981) in Didelphys albiventris from Santiago del Estero, in Thylamys pusilla (= pusillus) from Mendoza and Lestodelphis halli from Rio Negro (Navone 1989) and in Thylamys pallidior and Trimeresurus venustus from Salta and Jujuy (Ramallo \& Claps 2007). Navone (1989) stated that dasipodids and didelphids (marsupials) established over 60 million years ago in South America and that parasitism by rictulariids must have been established before the arrival of the cricetids during the Pliocene-Pleistocene time period. Pterygodermatites (P.) spinicaudatis Navone and Suriano, 1992 was found in Microbiotheria (= australis) from Rio Negro (Navone
\& Suriano 1992); Pterygodermatites (P.) zygodontomys from Bolomys (= Zygodontomys) lasiurus, Graomys (=Phyllotys) grisoflavus and A. azarae and Pterygodermatites (P.) jagerskjoldi in Caluromys phillander, whose distribution extends from Southern Mexico to Northern Argentina (Lent \& Texeira de Freitas 1935).

O'Brien and Etges (1981) registered seasonal fluctuations in the parasitic load of Pterygodermatites coloradensis in the rodent Promyscus leucopus. These researchers argue that seasonality may be due to the short life of the adult parasite in the gut of the host, and/or to the availability of infected hosts. In addition, they report that the intensive feeding on grasshoppers outside the caves in the spring and summer months expose rodents to higher loads of parasites. The constant conditions inside the caves, with sheltered and warmer environmental conditions, could facilitate the persistence of viable eggs throughout the winter. In this regard, the presence of Pterygodermatites $\mathrm{sp}$. in rodent faecal samples from Alero Mazquiarán would indicate that they could have been deposited in the most active months (spring-summer). Eggs found in this study are larger than those reported from other rodent and didelphid species (Table) and may belong to a new species and a possible new host in Argentina, 
TABLE

Pterygodermatites species records in Argentina and egg measurements in micrometers

\begin{tabular}{lccll}
\hline & \multicolumn{2}{c}{ Egg measurements $(\mu)$} & \\
\cline { 2 - 3 } Pterygodermatites sp. & Length range mean & Width range mean & References \\
\hline$P .(P$.$) massoiai$ & $32-36$ & 24 & & Sutton 1979 \\
$P .(P$.$) chaetophracti$ & $36-40(38)$ & $24-26(28)$ & & Navone \& Lombardero 1980, Navone 1987 \\
$P .(P$.$) azarai$ & $32-40$ & $24-28$ & & Sutton 1984, Navone 1989, Ramallo \& Claps 2007 \\
$P .(P$.$) kozeki$ & $21-39(31)$ & $18-27(24)$ & & Navone 1989 \\
$P .(P$.$) spinicaudatis$ & $30-50(40)$ & $20-40(30)$ & & Navone \& Suriano 1992 \\
$P .(P$.$) jagerskjoldi$ & $38-46$ & $24-30$ & Lent \& Texeira de Freitas 1935 \\
$P .(P$.$) zygodontomys$ & without measurements & without measurements & Lent \& Texeira de Freitas 1935 \\
Pterygodermatites sp. & $48.75-51.25$ & $35-37.5$ & & Present finding \\
& $(51.72 \pm 2,4)$ & $(37.97 \pm 1.88)$ & \\
\hline
\end{tabular}

current or extinct. This represents the first paleoparasitological report of this nematode genus worldwide.

The family Trichosomoididae consists of only four genera of nematode parasites: Anatrichosoma (in the oral cavity of marsupials), Huffmanela (in the gills and other organs of sharks), Trichuroides (in the bladder of bats) and Trichosomoides (in the urinary tract of rodents). Eggs of trichosomoidids have characteristics resembling those of trichinellids, being completely embryonated when deposited, thick-walled and having dark shells (Moravec 2000, 2001). Thomas (1924) described the cycle of $T$. crassicauda, a parasite of the urinary bladder of Rattus norvegicus, exhibiting the peculiar characteristic that the male is parasitic to the female uterus. This parasite produces papillomas, which are highly pathogenic to the host. The author of this study experimentally reported the zoonotic potential of this nematode in dogs. Eggs are eliminated with the urine of rats in groups, with the production of adhesive substances. Parasites found in X-11 coprolites were identified as Trichosomoides and likely T. crassicauda (Bellingham 1840, Raillet 1895). While it is a parasite of the rodent urinary system, the presence in faeces would likely be due to contamination of faeces with urine. The present study constitutes the first time that this nematode genus is cited from old or new material in Argentina.

Cestodes are common parasites in small mammals (insectivorous, lagomorphs, bats and rodents). They appeared long before the origin of mammals and their hosts accompanied them wherever they were. Whether as intermediate or as a definitive host, rodents provided excellent opportunities for cestodes to diverge in both geographic area and time, playing a major role in the evolutionary ecology of their hosts. The passage of cestodes from one host to another occurs through food webs (Georgiev et al. 2006). All cestode species listed as adults in rodents belong to six families and 47 genera within the order Cyclophyllidea: Catenotaeniidae, Hymenolepididae, Anoplocephalidae, Paruterinidae, Davaineidae and Dilepydidae. Hymenolepididae and Anoplocephalidae (45 genera and 25 , respectively) are very well represented in small mammals (Wickström et al. 2005). Intermediate hosts for cestodes in small mammals include the terrestrial arthropods (insects, mites, and also myriapods and arachnids). Anoplocephalids recorded at the current time in rodents are representatives of the following genera: Andrya, Anoplocephaloides (= Paranoplocephaloides), Bertiella (= Indotaenia), Ctenotaenia, Diandrya, Gallegoides, Hokkaidocephala, Moniezia, Monoecocestus, Parandrya, Paranoplocephala, Pseudocittotaenia, Sdarikovina, Viscachataenia, Mathevotaenia (= Schizorchodes), Sinaiotaenia, Witenbergitaenia, Inermicapsifer and Metacapsifer (Beveridge 1994, Georgiev et al. 2006). Beveridge (1994) stated that Moniezia consists of a diverse collection of cestodes. In addition to the well-documented records in ruminants and suids, their normal hosts, there is only one species in rodents (Monoecocestus bequarti). Beveridge (1994) states that the genus structure needs serious revision, as many of the records of cestodes attributed to Moniezia were found in rodents, do not correspond to the genus, and are mainly Monoecocestus. Tenora (1976) examined the taxonomy of anoplocephalids both globally and in South America and Rego (1961) conducted a review of the genus Monoecocestus Beddard, 1914, recording several parasitic species from rodents living in Brazil, Paraguay, Perú and Chile. These species included Monoecocestus hagmanni from Hydrochoerus hydrochoeri, eggs: 50 x $63 \mu \mathrm{m}$ (Brazil); Monoecocestus hydrochoeri from H. hydrochoeri, eggs: 50 × $67 \mu \mathrm{m}$ (Paraguay and Brazil); Monoecocestus parcitesticulatus from Cavia porcellus; eggs: $50 \mu \mathrm{m}$ (Brazil); Monoecocestus minor from Brazilian guinea pig, eggs: $50 \mu \mathrm{m}$ (Brazil) and Monoecocestus macrobursatum from $H$. hydrochoeri, eggs: 50 x 58 $\mu \mathrm{m}$ (Brazil). Magalhães Pinto et al. (2002) reported $M$. parcitesticulatus in $C$. porcellus with eggs 40-51 (average: 47) x 25-28 (average: 26) $\mu \mathrm{m}$.

In Argentina, Sutton (1973) described a new species, Monoecocestus myopotami, in the otter Myocastor coypus, with eggs $53.3 \mu \mathrm{m}$ long and $53.6 \mu \mathrm{m}$ wide. These eggs harboured a pyriform apparatus excluding any terminal filaments. Navone (1988) cited the pres- 
ence of anoplocephalids in three species of dasypodids, belonging to the genus Mathevotaenia: Mathevotaenia surinamensis in Dasypus novemcinctus of Corrientes, and described two new species: Mathevotaenia diminuta in Chaetophractus vellerosus of Formosa and Mathevotaenia matacus in T. matacus from Chaco. Denegri et al. (2003) created a new genus and species to incorporate Viscachataenia quadrata, the parasite of Lagidium viscacia, a rodent of the family Chinchillidae endemic in Argentina, whose eggs measured 15-19 $\mu \mathrm{m}$ (average: 17) in diameter, and with a pyriform apparatus elongated, and four lobes of different sizes. Recently, Wickström et al. (2005), in a phylogenetic analysis of morphological and molecular genitalia of nine genera and 35 species of anoplocephalids, established that the majority of the radiation of the group was among rodents and lagomorphs. They distinguished a large monophyletic group that includes all species of arvicoline rodents (voles and lemmings), primarily represented by the genera Anoplocephaloides and Paranoplocephala. Intermediate hosts for these cestodes are Oribatid mites and are ingested by herbivorous where infection occurs. In this regard, Denegri et al. (2002) confirmed the role of Zygoribatula striassima and Oribatella $\mathrm{sp}$. in the transmission of Thysanosoma actinioides. Anoplocephalids can cause human disease if humans eat mites present in the soil (Denegri et al. 1998).

Fugassa (2006a, b) found coprolites eggs attributed to Moniezia sp. in sample X-10, although we stated that rodents have not yet been reported as hosts for this anoplocephalid genus. Re-examination of the material carried out in the present study identified these eggs as Monoecocestus sp. Freeman (2004) reported that full development of cysticercoids of Monoecocestus americanus and Monoecocestus variabilis take place between $15-25^{\circ} \mathrm{C}$. As related with this report, together with the finding of Pterygodermatites, it is possible that faeces examined in this study would have been deposited in the sediment of the pelvic cavity in the archaeological site during the warmer months.

From the pelvic sediment, one egg of Trichuris, two eggs of anoplocephalids and many remnants of mites (deutonymph hyponus) were reported by Fugassa (2006a, b). In X-11 coprolites, we discovered an unidentified ascaridid, one egg of Capillaria sp., and one egg of Trichuris. Some of the parasites cited by Fugassa (2006a, b) were not found in this study (i.e., ascaridid and Capillaria) and vice versa (Pterygodermatites). With respect to the finding of Trichuris and Capillaria in rodent coprolites (sample X-11) by Fugassa (2006a, b), it probably was erroneously identified, corresponding to Trichosomoides sp.

The behaviour of the aboriginals living in Patagonia during the XIX century can partially explain the parasite findings of rodent parasites in the burial examined. Domeyko (Pérez de Micou 2006) cited that it was common in the past to offer food to the dead, who spent days above ground before burial. This type of situation is conducive to rodents coming in search of food and depositing their faeces, thereby contaminating the area. In this case, the faeces may have been deposited in the pelvic cavity, with the parasites contained in the faecal material.

\section{ACKNOWLEDGEMENTS}

To the archaeologists A. M. Aguerre and C. Pérez de Micou, for samples, to U. Pardiñas, for the information of rodents, to F. Moravec, for the bibliography and comments on Trichosomoides, and to the anonymous reviewers in an earlier version of the manuscript.

\section{REFERENCES}

Anderson RC 2000. Nematode parasites of vertebrates: their development and transmission, CAB International, Wallingford, $650 \mathrm{pp}$.

Beldoménico PM, Kinsella JM, Uhart MM, Gutiérrez GL, Pereira J, Ferreira HDV, Marutti C 2005. Helmintos of Geoffroy's cat, Oncifelis geoffroyi (Carnivora: Felidae) from the Monte desert, Central Argentina. Acta Parasitol 50: 263-266.

Beveridge I 1994. Family Anoplocephalidae Cholodkovsky, 1902. In LF Khalil, A Jones, RA Bray, Key to the cestode parasites of vertebrates, CAB International, Wallingford, p. 315-366.

Brooks DR 1979. Testing the context and extent of host-parasite coevolution. Syst Zool 28: 299-307.

Chame M 2003. Terrestrial mammal feces: a morphometric summary and description. Mem Inst Oswaldo Cruz 98: 71-94.

Denegri G, Bernardina W, Pérez-Serrano J, Rodríguez Caabeiro F 1998. Anoplocephalidae cestodes of veterinary and medical significance: a review. Folia Parasitol 45: 1-8.

Denegri G, Dopchiz MC, Elissondo MC, Beveridge I 2003. Viscachataenia n. g., with the redescription of V. quadrata (von Linstow, 1904) n. comb. (Cestoda: Anoplocephalidae) in Lagidium viscacia (Rodentia: Chinchillidae) from Argentina. Syst Parasitol 54: 81-88.

Denegri G, Elissondo MC, Dopchiz MC 2002. Oribatid mites as intermediate hosts of Thysanosoma actinioides (Cestoda: Anoplocephalidae): a preliminary study. Vet Parasitol 103: 267-271.

Freeman RS 2004. Temperature as a factor affecting development of Monoecocestus (Cestoda: Anoplocephalidae) in oribatid mites. Exp Parasitol 1: 256-262.

Fugassa MH 2006a. Enteroparasitosis en poblaciones CazadorasRecolectoras de Patagonia Austral, PhD Thesis, Universidad Nacional de Mar del Plata, 276 pp.

Fugassa MH 2006b. Exámen paleoparasitológico de sedimentos de un sitio arqueológico, Río Mayo, Chubut, Argentina. Parasitol latinoam 61: 172-175.

Georgiev BB, Bray RA, Littlewood TJ 2006. Cestodes of small mammals: taxonomy and life cycles. In S Morand, BR Krasnov, R Poulin, Micromammals and macroparasites. From evolutionary ecology to management, Springer-Verlag, Tokio, p. 29-62.

Jouy-Avantin F 2003. A standarized method for the description and study of coprolites. J Archaeol Sci 30: 367-372.

Lent H, Texeira de Freitas JP 1935. Sobre dois novos nematodeos parasitos de quica: Caluromys phillander (L.). Mem Inst Oswaldo Cruz 30: 535-542.

Lutz A 1919. Schistosoma mansoni e a schistosomatose segundo observações feitas no Brasil. Mem Inst Oswaldo Cruz 1: 121-155.

Magalhães Pinto R, Corrêa Gomes D, Muniz-Pereira LC, Noronha D 2002. Helminths of the Guinea pig, Cavia porcellus (Linnaeus), in Brazil. Rev Brasil Zool 19: 261-269.

Manter HW 1967. Some aspects of the geographical distribution of parasites. J Parasitol 53: 1-9.

Monjeau JA, Sikes RS, Birney EC, Guthmann N, Phillips CJ 1997. Small mammal community composition within the major landscape divisions of Patagonia, Southern Argentina. Mastozool Neotrop 4: 113-127. 
Morand S, Krasnov B, Poulin R, Degen A 2006. Micromammals and macroparasites: Who is who and how they interact? In $\mathrm{S}$ Morand, BR Krasnov, R Poulin, Micromammals and Macroparasites. From evolutionary ecology to management, SpringerVerlag, Tokio, p. 3-9.

Moravec F 2000. Review of capillariid and trichosomoidid nematodes from mammals in the Czech Republic and the Slovak Republic. Acta Soc Zool Bohem 64: 271-304.

Moravec F 2001. Trichinelloid Nematodes parasitic in cold-blooded vertebrates, Academia, Praha, 429 pp.

Navone GT 1987. Descripción del macho de Pterygodermatites (Paucipectines) chaetophracti (Navone y Lombardero, 1980) Sutton, 1984 (Nematoda: Rictulariidae). Neotrópica 33: 45-49.

Navone GT 1988. Estudios parasitológicos en edentados Argentinos. IV. Cestodes pertenecientes a la familia Anoplocephalidae Cholodkovsky, 1902, parásitos de Dasypópidos. Neotrópica 34: 51-61.

Navone GT 1989. Pterygodermatites (Paucipectines) kozeki (Chabaud et Bain, 1981) n. comb. Parásito de Lestodelphis halli Tate, 1934, Didelphys albiventris y Thylamys pusilla (Desmarest) de la República Argentina. Anatomía y posición sistemática. Rev Ibér Parasitol 49: 219-226.

Navone GT, Lombardero O 1980. Estudios parasitológicos en edentados Argentinos. I. Pterygodermatites (Pterygodermatites) chaetophracti sp. nov. en Chaetophractus villosus y Dasypus hybridus (Nematoda: Spirurida). Neotrópica 26: 65-70.

Navone GT, Suriano DM 1992. Pterygodermatites (Paucipectines) spinicaudatis n. sp. (Nematoda: Rictularidae) from Dromiciops australis (Marsupialia: Microbiotheriidae) in Bariloche, Rio Negro, Argentina. Biogeographical distribution and host-parasite relationships. Mem Inst Oswaldo Cruz 87: 533-538.

O’Brien RT, Etges FJ 1981. Overwintering population changes of Pterygodermatites coloradensis (Nematoda: Rictulariidae) in Kentucky and Ohio. Ohio J Sci 81: 114-119.

Pardiñas UFJ, Teta P, Cirignoli S, Podestá DH 2003. Micromamíferos (Didelphiomorpha y Rodentia) de Norpatagonia Extra Andina, Argentina. Taxonomía Alfa y biogeografía. Mastozool Neotrop/J Neotrop Mammal 10: 69-113.

Pérez de Micou C 2006. Textiles arqueológicos de la Patagonia Ar- gentina. Hallazgos en el sito Alero Mazquiarán, Actas de la XIX Reunión Anual de la Comisión Nacional de Conservación Textil, México, 7pp.

Pike AW 1968. Recovery of helminth eggs from archaeological excavations and their possible usefulness in providing evidence for the purpose of an occupation. Nature 219: 303-304.

Poulin R 2007. Evolutionary ecology of parasites, Princeton University Press, New Jersey, 332 pp.

Quentin JC 1969. Essai de classification de Nématodes Rictulaires. Mém Mus Natl Hist Natur Sér A Zool 56: 55-115.

Ramallo G, Claps LE 2007. Nuevos hospedadores y registros geográficos de Pterygodermatites (Paucipectines) kozeki (Nematoda: Rictulariidae) en Argentina. Mastozool Neotrop 14: 93-96.

Rego AA 1961. Revisão do gênero Monoecocestus Beddard, 1914 (Cestoda: Anoplocephalidae). Mem Inst Oswaldo Cruz 59: 325-354.

Sutton CA 1973. Un nuevo Eucestode parásito de Myocastor coypus bonariensis Commerson. Neotrópica 19: 38-42.

Sutton CA 1979. Contribución al conocimiento de la fauna parasitológica argentina. IV. Rictularia massoiai sp. n. y Enterobius yagoi sp. n. (Nematoda). Acta Zool Lilloana 35: 29-37.

Sutton CA 1984. Contribución al conocimiento de la fauna parasitológica argentina. XIII. Nuevos nematodos de la familia Rictulariidae. Neotrópica 30: 141-152.

Tenora F 1976. Tapeworms of the family Anoplocephalidae Cholodkowsky, 1902. Evolutionary implications. Acta Sc Nat Brno 10: $1-37$.

Teta P, Andrade A, Pardiñas UFJ 2005. Micromamíferos (Didelphiomorphia y Rodentia) y paleoambientes del Holoceno tradío en la Patagonia noroccidental extra-andina. Archaeofauna 14: 183-197.

Thomas LJ 1924. Studies on the life history of Trichosomoides crassicauda (Bellingham). J Parasitol 10: 105-145.

Wickström LM, Haukisalmi V, Varis S, Hantula J, Henttonen H 2005. Molecular phylogeny and systematics of anoplocephalinae cestodes in rodents and lagomorphs. Syst Parasitol 62: 83-99.

Williams HH, MacKenzie K, McCarhty AM 1992. Parasites as biological indicators of the population biology, migrations, diet, and phylogenetics of fish. Rev Fish Biol Fish 2: 144-176. 